\title{
Nutritional status and blood pressure assessment in vulnerable children from two schools in Cutral Co and Plaza Huincul. A quantitative and qualitative study
}

\author{
Martín Sapag, M.D. ${ }^{a}$, Carolina Dioverti, M.D. ${ }^{a}$, Lorena Paramio, M.D. ${ }^{a}$, \\ Ana Petronace, M.D. ${ }^{a}$, Florencia Rao, Nurse ${ }^{a}$, Alejandra Aroca, Nurse ${ }^{a}$, \\ Sonia Figueroa, B.S. ${ }^{a}$, Roberto Llancaqueo, Nurse ${ }^{a}$, Carolina Mussin, M.D. ${ }^{a}$, \\ Gabriela Shell, Engineering Student ${ }^{a}$ Leonardo Tapia, Social Worker ${ }^{a}$, and \\ Jorgelina Parola, M.D. ${ }^{a}$
}

\begin{abstract}
Introduction. Knowing the nutritional status of children is critical to plan primary health care interventions in the setting of the present obesity epidemic and the great increase in the prevalence of childhood metabolic syndrome.

For this reason, nutritional status and blood pressure were assessed among children from two schools of high social vulnerability, results were qualitatively analyzed, and community members feedback was obtained in order to be fully aware of the situation and accordingly plan local health interventions.

Population and methods. Cross-sectional study conducted at purposively selected schools, with results analyzed using focus groups.

The following standards were used: the World Health Organization (WHO) growth standards for weight and height; the National Center for Health Statistics (NCHS) for body mass index (BMI); the National Institutes of Health (NIH) for blood pressure; and Fernández J., et al. standards for waist circumference.

Results. Three hundred and sixty one children were evaluated; of them, $20.8 \%$ were overweight, $22.2 \%$ were obese and $6.5 \%$ were hypertensive. Obesity was more prevalent in boys ( $p: 0.039$ ), and no relationship was observed between hypertension and central obesity with age and sex. The social factors that influence this situation were described by community representatives. Conclusions. It was established that this population was malnourished and had a high prevalence of obesity. Results were analyzed by community members who focused on the items to be considered for the intervention.

Key words. prevention and control, school health, anthropometry, obesity.
\end{abstract}

a. Hospital Cutral Co-Plaza Huincul. Neuquén, Argentina

E-mail Address:

Martín Sapag M.D., canaan_2@yahoo.com.ar

Conflict of Interest:

None.

Received: 7-14-2013

Accepted: 2-5-2014 http:/ /dx.doi.org/10.5546/aap.2014.eng.337

\section{INTRODUCTION}

The relevance of a collective assessment of children's nutritional status lays in that results obtained in a specific community are representative of factors related to upbringing and diet conditions.
Therefore, the way children grow is also indicative of whether their rights are being warranted and provides input on how to plan local primary care actions.

It is known that, at a national and provincial level, obesity has become highly prevalent and relatively important in terms of short stature and malnutrition in the pediatric population, and this has also been demonstrated worldwide by the emergence of a true obesity epidemic. ${ }^{3}$

In addition, a consensus of international experts has underscored the significance of screening for the metabolic syndrome in children, a condition related to the development of diabetes and cardiovascular disease in adults, consisting of several risk factors including arterial hypertension, obesity, hyperglycemia and dyslipemia. ${ }^{4}$

Based on these prior concepts, we decided to assess nutritional status and blood pressure at two schools located in Cutral Co and Plaza Huincul, purposively selected for this intervention for two reasons: they are located in neighborhoods with a high social vulnerability where serious family and community violence episodes are commonplace. ${ }^{5-9}$ Such violence led to the temporary shut down of the neighborhood schools and health care center and the discontinuation of other community activities during the study period. Besides, both schools evidenced a high motivation to network, taking part in promotion and prevention activities together with the local health 
care center, ${ }^{10}$ enabling counseling in health situations that combine biological and social problems.

The educational community became an active player in the project, which combined a quantitative assessment and a qualitative analysis using focus groups. The objective of this methodological triangulation was to obtain the most of results so as to become aware of social actors opinions regarding the health status of children, because underlying ideas are critical for primary healthcare planning. ${ }^{11}$

\section{OBJECTIVES}

To conduct an anthropometric evaluation of metabolic syndrome indicators among male and female students attending primary school No. 63 in Cutral Co and primary school No. 334 in Plaza Huincul.

To identify community members opinions on the causes of quantitative results.

\section{POPULATION AND METHODS}

Study conducted between September 2012 and April 2013 at two primary schools in Cutral Co and Plaza Huincul, purposively selected among 25 primary schools in both cities.

The decision to carry out the study and the selection of outcome measures to be examined was made during the community network meetings held at Hospital Cutral Co-Plaza Huincul, with the participation of teachers from both schools.

The aim was to evaluate more than $90 \%$ of students from each school, with 162 students enrolled at school No. 334 and 216 enrolled at school No. 63.

The perspective of rights implied in this study influenced the selection of reference standards. At present, the population younger than six years old is assessed as per theWorld Health Organization (WHO) prescriptive standards, ${ }^{12}$ adopted by the Ministry of Health of the Republic of Argentina ${ }^{13}$ and adhered to by the Sociedad Argentina de Pediatría (SAP). ${ }^{14}$ However, for the population older than six years old, there are no ideal international growth standards available, only national descriptive standards for weight and height, and the WHO and National Center for Health Statistics (NCHS) standards for body mass index (BMI).

Therefore, in this study, it was agreed to use WHO standards for weight and height, adjusted as per international references for children younger than six years old ${ }^{15}$ and because they are the more demanding than national standards.

In order to warrant viability, waist circumference and blood pressure were selected as metabolic syndrome indicators according to Fernández J. R., et al. references ${ }^{16}$ and reference patterns recommended by the National Institutes of Health (NIH), ${ }^{17}$ respectively.

Results obtained during the quantitative stage were analyzed by representatives of the educational community using the focus group technique. $^{18}$

\section{Design}

Cross-sectional study with an analysis of focus groups data.

\section{Quantitative stage}

Inclusion criteria: first through seventh grade students from selected schools.

Exclusion criteria: students with specific growth standard conditions different from those of the general population (for example, Down's syndrome).

\section{Outcome measures}

Weight and height: measured with a beam scale with a capacity up to $150 \mathrm{~kg}$ and $100 \mathrm{~g}$ precision, with the child wearing light clothing and barefoot. The stadiometer attached to the scale was used, which has $1 \mathrm{~mm}$ precision. BMI (weight/height ${ }^{2}$ ) and height-for-age and weightfor-age percentiles were estimated.

Cut-off points for overweight and obesity were the $85^{\text {th }}$ and $97^{\text {th }}$ percentiles, respectively, while the $3^{\text {rd }}$ percentile was considered for short stature and underweight.

Waist circumference: measured using a tape measure positioned at the right superior border of the iliac crest, and using the $90^{\text {th }}$ percentile as the cut-off point.

Blood pressure: measured using an aneroid sphygmomanometerwith a cuff size in relation to arm circumference and the child sitting down. Values were classified according to the age, sex and height; values under the $90^{\text {th }}$ percentile were considered normal blood pressure, values between the $90^{\text {th }}$ and $95^{\text {th }}$ percentiles were considered prehypertension, values between the $95^{\text {th }}$ and $99^{\text {th }}$ percentiles were considered stage 1 hypertension, and above the $99^{\text {th }}$ percentile, stage 2 hypertension.

A team of field operators (nurses, teachers and doctors) was trained on measurement techniques based on SAP recommendations. ${ }^{19}$ 
Average and dispersion values (standard deviation, Z-score and sampling range) were estimated to analyze anthropometric and blood pressure data. The Epilnfo software, version 3.5.3., was used for univariate and bivariate analyses. Plots were prepared in Microsoft Office Excel 2007.

\section{Qualitative stage}

Teachers, students and their parents, and local healthcare agents were convened. Children and parents were randomly selected by drawing lots using the quantitative stage data, warranting the inclusion of obese and non-obese children. Teachers and healthcare agents attended the meetings once designated by their chiefs and directors and according to services they provided.

All participating adults were administered a survey on cardiovascular risk factors ${ }^{20}$ (Annex 1); this survey is used by the Health Department of Neuquén (SSPN) for preselecting cardiovascular risk patients in the city of Neuquén, ${ }^{21}$; afterwards their weight and height were measured. The results of this evaluation were shown during the meeting for participants to focus on them.

Initially, the reasons and objectives of the study were explained, results were presented on a Power Point file which was easy to understand by participating children and adults who then were invited to divide into groups according to their role, coordinated and guided by two trained participants. The script included an open question oriented to knowing participants' opinions on the described problem and other close-ended questions to look into the causes of the research findings.

Each group designated a spokesperson, who shared the findings at the end of the activity in order to draw common conclusions.

Participants' opinions were processed by the research team, who focused on general causes of obesity, differences in relation to sex and results obtained regarding the sample height.

Ethical considerations: The SSPN approved the project by Resolution No. 1562/12. Directors and parents signed an informed consent and participating children gave their assent.

\section{Quantitative stage results}

Three hundred and sixty one children from both schools were evaluated, accounting for $93.8 \%$ of all students from school No. 334 and $96.7 \%$ from school No. 63 . Five children were not evaluated because their parents did not give their consent and twelve because they missed school on the day of measurement. Personal and anthropometric characteristics of children are described in Table 1.

Results are complemented with frequency distribution curves of height and BMI, showing a relationship with reference patterns. The distribution curve of height-for-age (Figure 1) showed an almost perfect agreement with the $\mathrm{WHO}$ curve, with a median of -0.07 standard deviations in relation to the reference and a standard deviation of 1.02. In addition, the curve of BMI-for-age showed a deviation towards overweight and obesity (Figure 2), with a bimodal distribution and statistically significant differences for sex, with higher overweight and obesity values in boys ( $\mathrm{X} 2$ : 8.3, $p$ : 0.039).

No statistically significant differences were observed when comparing sex and height or sex and waist circumference. Likewise, no statistically significant differences were found when establishing a relationship between age

TABLE 1. Personal characteristics and distribution by anthropometric outcome measures and clinical indicators of metabolic syndrome in male and female children from schools No. 63 and 334 in Cutral Co and Plaza Huincul, year 2012, n: 361

\begin{tabular}{lc}
\hline & \\
Outcome measure & Values \\
\hline Age (years) & \\
Range & $6-15$ \\
Average & 10 \\
Median & 9.96 \\
Sex & \\
Female & $187(51.9 \%)$ \\
Male & $174(48.1 \%)$ \\
Children evaluated by school & \\
No. 63 & $209(57.9 \%)$ \\
No. 334 & $152(42.1 \%)$ \\
Body mass index & \\
Standard & $206(57,1 \%)$ \\
Overweight & $75(20.8 \%)$ \\
Obesity & $62(17.2 \%)$ \\
Severe obesity & $18(5 \%)$ \\
Low weight & $0(0 \%)$ \\
Tall stature & $10(2.8 \%)$ \\
Abdominal circunference & \\
Lower than or equal to 90 th percentile & $286(78.9 \%)$ \\
Higher than 90th percentile & $75(21.1 \%)$ \\
Blood pressure & \\
Normal & $337(93.3 \%)$ \\
Prehypertensive & $19(5.2 \%)$ \\
Stage 2 hypertension & $5(1.3 \%)$ \\
\hline & $0(0 \%)$ \\
\hline & \\
Stage Hypertension & \\
\hline
\end{tabular}


340 / Arch Argent Pediatr 2014;112(4):337-344 / Original article

FIGURE 1. Distribution of height/age of students from schools No. 63 and 334 in Cutral Co and Plaza Huincul

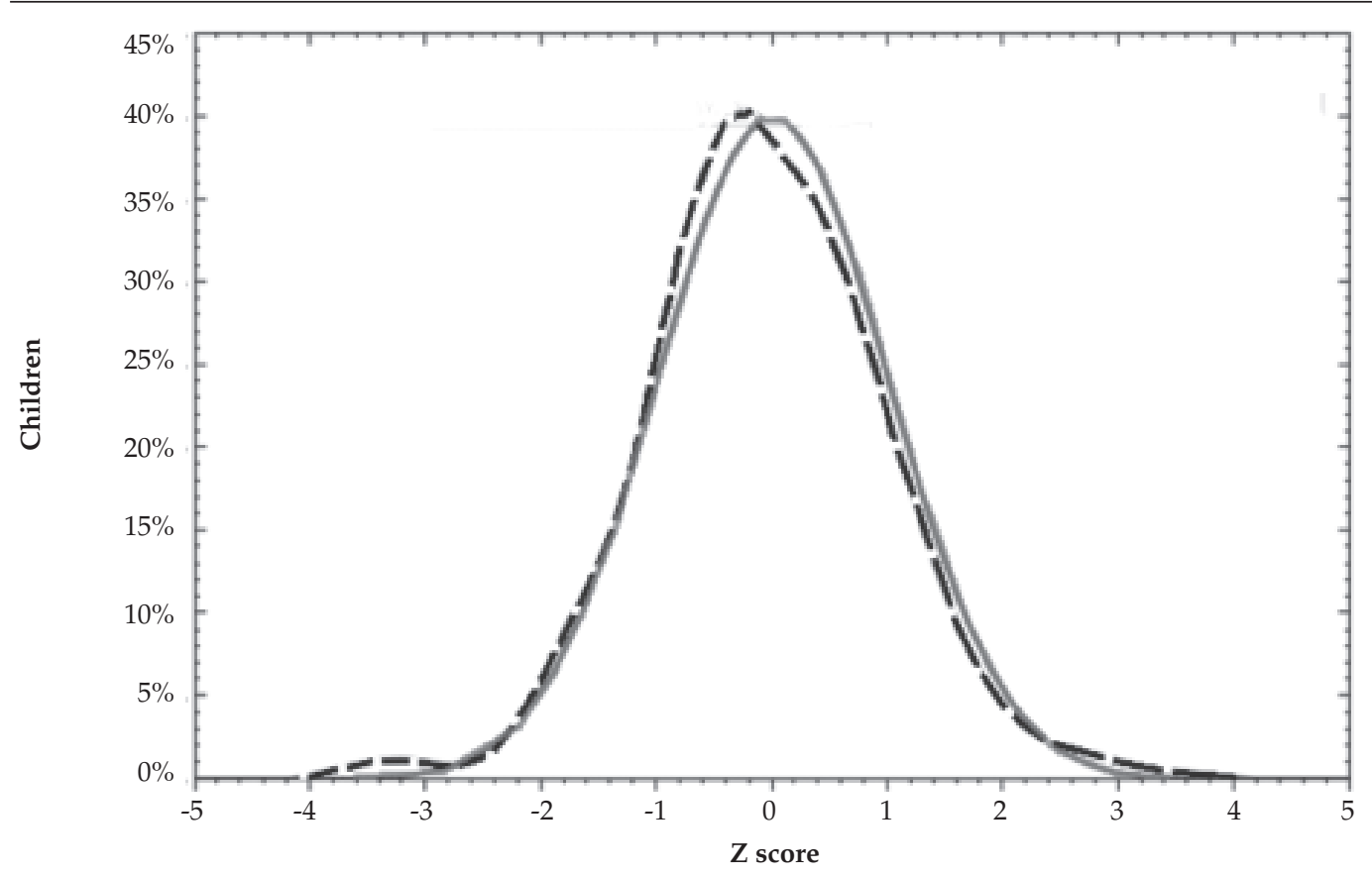

WHO standards (from birth to 60 months old), WHO 2007 reference (61 months old to 19 years old).

- - All surveyed children $(\mathrm{n}=361)$.

Figure 2. Distribution of BMI/age of students from schools No. 63 and 334 in Cutral Co and Plaza Huincul

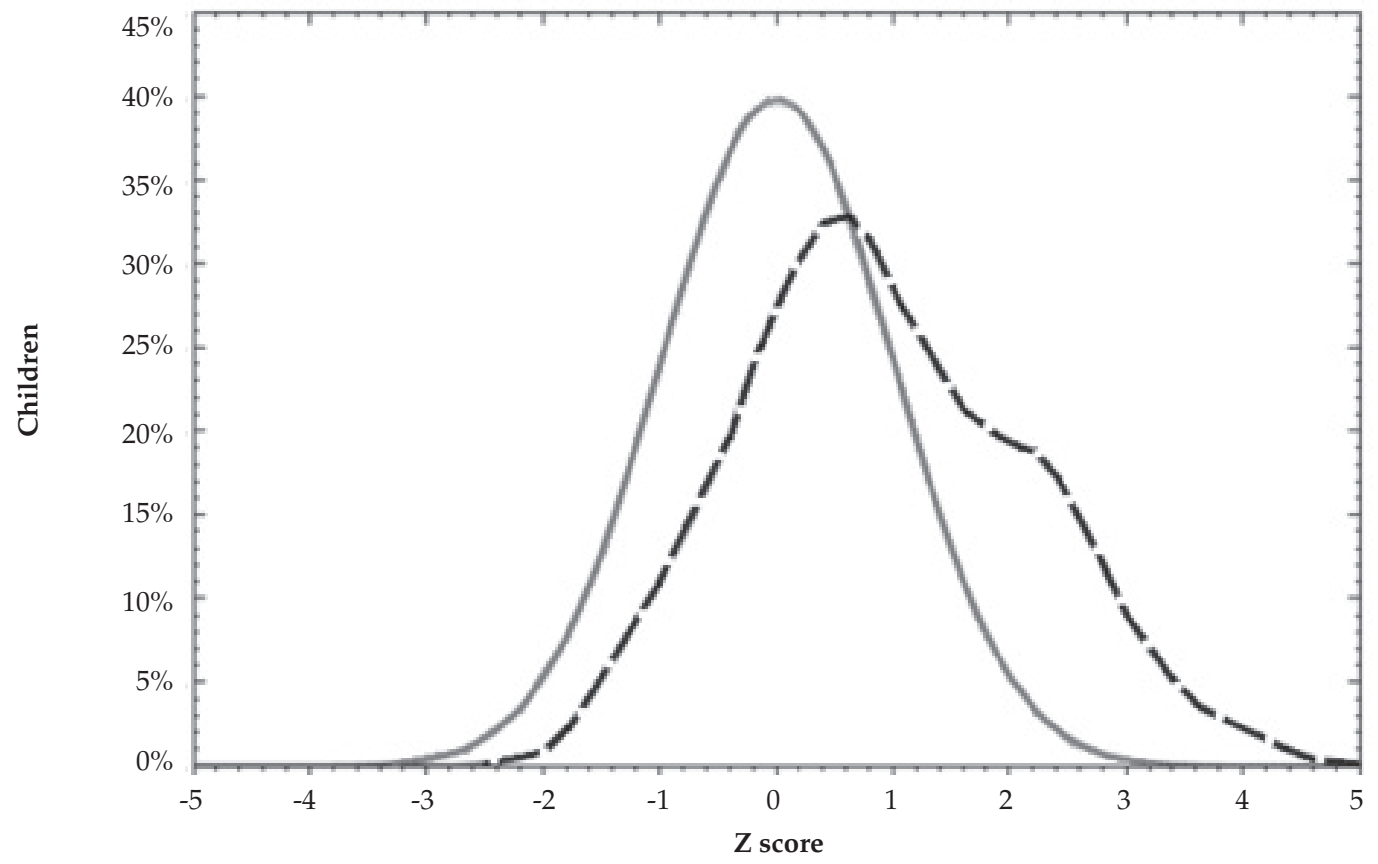

WHO standards (from birth to 60 months old), WHO 2007 reference (61 months old to 19 years old).

- - All surveyed children $(\mathrm{n}=361)$. 
and school and the different studied outcome measures. Similarly, no significant relationship was found when analyzing the relationship among blood pressure values and waist circumference and body mass index results.

However, when comparing BMI and height results, statistically significant differences were observed (X2: 25.8, p: 0.0002); tall stature values were predominant in the overweight and obese children group (Table 2).

\section{Qualitative stage results}

the meeting was attended by 36 community members. Their characteristics are described in Table 3.

Of participating adults, $27.7 \%$ were overweight, $47.2 \%$ were obese and $57.5 \%$ had a middle or high cardiovascular risk.

Table 4 is based on participants' opinions and describes the possible causes of obesity and the alleged responsibility assigned to each cause according to the group participants' feedback.

Although there were no differences among groups in terms of the most relevant core ideas

TABLE 2. Relation between body mass index and stature results in male and female children from schools No. 63 and 334 in Cutral Co and Plaza Huincul, n: 361

\begin{tabular}{lccc}
\hline $\begin{array}{l}\text { Body mass } \\
\text { index }\end{array}$ & $\begin{array}{c}\text { Short } \\
\text { stature }\end{array}$ & $\begin{array}{c}\text { Standard } \\
\text { stature }\end{array}$ & $\begin{array}{c}\text { Tall } \\
\text { stature }\end{array}$ \\
\hline Normal & $8(3.9 \%)$ & $197(95.6 \%)$ & $1(0.5 \%)$ \\
Overweight & $0(0 \%)$ & $73(97.3 \%)$ & $2(2.7 \%)$ \\
Obesity & $0(0 \%)$ & $58(93.5 \%)$ & $4(6.5 \%)$ \\
Severe obesity & $0(0 \%)$ & $15(83.3 \%)$ & $3(16.7 \%)$ \\
\hline
\end{tabular}

TABLE 3. Personal characteristics of participants of nutritional status focus groups regarding male and female children from schools No. 63 and 334 in Cutral Co and Plaza Huincul, n: 36

\begin{tabular}{lcc}
\hline & $\mathbf{n}$ & $\mathbf{\%}$ \\
\hline Age & & \\
Children & 9 & 25,0 \\
Adults & 27 & 75.0 \\
Sex & & \\
Male & 9 & 25.0 \\
Female & 27 & 75.0 \\
Role & & \\
Students & 9 & 25,0 \\
Mothers-fathers & 8 & 22,2 \\
Teachers & 8 & 22,2 \\
Healthcare agents & 11 & 30,5 \\
\hline
\end{tabular}

identified as causes of obesity, there were some differences in the perspectives given to these aspects by each group.

Children tended to hold adults responsible (they claimed: "We need adults") and highlighted the monotony of foods offered at home and the lack of opportunities to do physical activity (one child complained: "Mom comes from work and takes a nap"). Additionally, parents referred they suffer great stress at work and feel tired when facing household chores, especially in the case of single-parent households. In relation to results showing that children had a standard stature for their age, during the meeting one of the mothers said: "Everyone's always talking about malnutrition, but the problem here is obesity!" which led the group to reflect on this issue, and one teacher admitted: "We have difficulties recognizing when someone has an average weight and when someone is obese."

Some obese adults discussed their situation and one of them, a healthcare agent, said:"I know I'm obese and I need help. I'm a healthcare agent and I can't talk about this unless I do something. I'm going to ask my son to help me start doing physical activity and developing healthy habits."

Except for children, the rest of the groups pointed out that violence on the streets is one of main causes for reducing opportunities for outdoor physical activity.

In relation to the differences observed in obesity in terms of sex, groups identified three reasons they believed caused this. Boys tend to spend more time in front of a screen (playing videogames or watching TV) and they consume high-calorie foods and beverages while doing it. Girls help with household chores; and given that television and commercials propose a model of social success in relation to thin women, parents tend to exercise more control on their daughters to prevent them from gaining weight.

\section{DISCUSSION}

Here we describe the nutritional status and blood pressure of a population of children aged 6 to 15 years old in a highly vulnerable position, together with the analysis by the educational community on the assessment results.

A higher prevalence of overweight and obesity and a taller than expected stature was observed when compared to national surveys on similar populations. ${ }^{1,2,22-24}$

Unlike the research quoted in the references, our study showed gender differences in terms of obesity distribution, with a higher prevalence 
in boys. The prevalence of hypertension was similar to that found in the study by Zeberio N., et al. ${ }^{25}$. However, no significant relationship was observed in our sample between hypertension and central obesity, although the more obese children were taller, an association pointed out by several authors, and related to the type of diet of preschool children. ${ }^{26}$
Although the studied population lives in a vulnerable setting, the prevalence of low weight and short stature was smaller than that reported in the province of Neuquén in $2004 .^{2}$ Such findings are probably related to certain strategies implemented by families to mitigate the effects of poverty, which have been described in previous local studies. ${ }^{27,28}$

TABle 4. Causes and sub-causes of obesity in students from schools No. 63 and 334 in Cutral Co and Plaza Huincul, classified according to the beliefs of each social actor in the educational community

Causes
$\begin{aligned} & \text { Social actor } \\ & \text { Students (both sexes) } \\ & \text { Preference for high-calorie } \\ & \text { foods and beverages (flour, candy, soft drinks) } \\ & \text { The more obese children are, } \\ & \text { the less physical activity they do and } \\ & \text { more high-calorie foods they consume. } \\ & \text { Low level of physical activity in children }\end{aligned}$

Mothers and fathers

Local community

Teachers

Snacks offered contain flour and sugar.

The school candy stand offers products that contain flour and sugar.

Missing school too often, therefore, less stimuli to do physical activity.
Little use of the activities offered by different institutions and groups in relation to physical activity.

Prefer to select and prepare foods with a

Low level of physical activity in the family. ittle variation ("monotony") in the foods offered at home.

\section{Sub-causes}

The food industry designs foods and its commercials in order to promote consumption in the population. Low self-esteem due to obesity. Bullying against obese children.

Many hours of sedentary lifestyle in front of a screen (TV, cell-phone, computers, etc.). Adults find it difficult to take their children to the park or do activities with them outdoors because they are tired after work or face limitations because of their single-parent family structure and have a small social support network.

\footnotetext{
Adults are tired after work. Little variety at the time of selecting and preparing foods.

Little variety when selecting and preparing foods.

Belief that children are at a "nutritional risk."

Lack of time in working adults. Apathy.
}

Unawareness of their own health status.

The State probably assumes that the student population is at a nutritional and malnutrition risk.

Need for additional economic resources for certain school expenses.

Violence in the neighborhood, which forces to close the school.

Violence in the neighborhood is a hurdle to the continuity of such activities.

Families are probably unaware of the possibilities offered in their neighborhoods in relation to physical activity.

\begin{tabular}{cc}
\hline Local healthcare agents & $\begin{array}{c}\text { Probably, a stronger focus on detecting } \\
\text { and following-up malnourished } \\
\text { children or children at a nutritional risk } \\
\text { instead of obese children. }\end{array}$
\end{tabular}

Source: focus groups with representatives of the educational community from both schools. 
The members of the educational community provided their opinions on the results and identified the different causes of childhood obesity. In addition, participating adults agreed on pointing out that, before knowing the results, they believed that malnutrition was more relevant than obesity. This is probably because health care teams are "conceptually focused on detecting malnutrition. ${ }^{\prime 29}$ During focus group discussions, children were identified as possible community health promoters and participants reflected on how sex-differentiated upbringing may be the cause of the higher prevalence of obesity in boys.

When it comes to establishing the causes, families agree with those described by different medical publications quoted in this discussion section, in addition to other specific causes related to their living conditions, i.e., a violent neighborhood, and how household members relate to one another. This shows that people have a prior knowledge that should not be underestimated if a primary care strategy is to be planned.

For this reason, we agree with other authors ${ }^{21,30,31}$ in that, when it comes to the nutritional status of children, two approaches need to be complemented: an individual health care approach (when medical knowledge takes precedence over other types of knowledge) and a collective approach (when the structure is based on the community and knowledge is horizontal). ${ }^{32}$

Since the sample was purposively selected, results are only representative of the reality at the schools included in the study and cannot be extrapolated to a wider population. However, researchers' objective in this study was not to obtain general results, but to focus on the community's problems and generate knowledge for local participatory actions. Results call for a future assessment with a sample representative of the general population and broader research on the context of upbringing that would allow to better understand the health/illness/care process in this community.

\section{CONCLUSIONS}

It was possible to establish the nutritional status and the presence of metabolic syndrome indicators in the students of selected schools, and a high prevalence of obesity has been observed.

The educational community pointed out the causes of the problems detected and focused on the items to be taken into account for a collective health care intervention.

\section{Acknowledgments}

To the families, teachers and healthcare agents of the Belgrano and surrounding neighborhoods, to the members of the Encuentro Network and to our colleagues at Hospital Cutral Co, Hospital Provincial Neuquén and the Health Department for their help with this study.

\section{REFERENCES}

1. MinisteriodeSaluddelaNación. EncuestaNacionaldeNutrición y Salud 2004-2005. Documento de presentación. [Accessed on: October 2013]. Available at: http:/ / msal.gov.ar/htm/Site/ennys/pdf/Documento_Presentacion.pdf.

2. Ministerio de Salud de la Nación. Encuesta Nacional de Nutrición y Salud 2004-2005. Síntesis informativa de la Provincia de Neuquén. [Acceso: octubre de 2013]. Availableat:http:/ / msal.gov.ar/htm/Site/ennys/download/ Sintesis \%20provincia \%20de\%20Neuquen.pdf.

3. Organización Mundial de la Salud. Estrategia mundial sobre régimen alimentario, actividad física y salud. Sobrepeso y obesidad infantiles. [Accessed on: November 2013]. Available at: http:/ /www.who.int/dietphysicalactivity / childhood/es/.

4. Alberti G, Zimmet P, Kaufman F, Tajima N et al. "International Diabetes Federation. Metabolic Syndrome in children and adolescents", 2007. [Accessed on: July 3, 2013]. Available at: http://www.idf.org/webdata/docs/Mets_ definition_children.pdf.

5. Cutral Co al instante. "Intentaron robar a auxiliares de servicio". [Accessed on: October 2013]. Available at: http:// www.cutralcoalinstante.com /index.php?option=com k2\&view=item\&id=6695:intentaron-robar-a-auxiliares-deservicio\&Itemid=198.

6. CutralCoalinstante."EscuelaN63:retoman actividades con policía adicional". [Accessed on: June 2013].Available at: http://www.cutralcoalinstante.com/index. php? option=com_k2\&view=item\&id=6852:escuelan\%C2\%B063-retoman-actividades-con-polic\%C3\%ADaadicional\&Itemid=194.

7. Cutral Co al instante. "Suspenden actividades en CPEM 20 por inseguridad". [Accessed on: October 2013]. Available at:http:/ / www.cutralcoalinstante.com/index. php?option $=$ com_k2\&view $=$ item \&id=7023:suspendenactividades-en-cpem-20-por-inseguridad\&Itemid=194.

8. CutralCoal instante. "Sucesión de agresiones en Barrio Belgrano". [Accessed on: October 2013]. Available at: http:/ / www.cutralcoalinstante.com/index.php?option=com_k2 \&view=item\&id=7006:sucesi $\%$ C3\%B3n-de-agresiones-enbarrio-belgrano\&Itemid=194.

9. Cutral Co al instante. "Apedrearon la Escuela $N^{\circ} 63^{\prime \prime}$. [Accessed on: October 2013]. Available at: http://www. cutralcoalinstante.com.ar $/$ index.php? option $=$ com k2\&view=item\&id=10030: apedrearon-la-escuelan\%C2\%B063\&Itemid=197.

10. Cutral Co al instante. "El centro de Belgrano ya es 'amigo de la Madre y el Niño'". [Accessed on: May 2013]. Available at: http://www.cutralcoalinstante.com.ar/index. php?option=com_k2\&view=item\&id=3036:el centrode-belgrano-ya-es-\%E2\%80\%9Camigo-de-la-madre-y-el ni\%C3\%B10\%E2\%80\%9D\&Itemid=197.

11. Minayo MC. El desafío del conocimiento. Investigación cualitativa de salud. Buenos Aires: Lugar Editorial, 2004.

12. WHO Multicentre Growth Reference Study Group. WHO Child Growth Standards: Methods and development. Length/ height-for-age, weight-for-age, weight-for-length, weight-for-height and body mass index-for-age. Geneva, 
World Health Organization, 2006. [Accessed on: July 3, 2013]. Available at:http://www.who.int/childgrowth/ standards/technical_report/en/index.html.

13. Ministerio de Salud de la Nación. Adopción de los patrones de crecimiento de la Organización Mundial de la Salud para niños. Resolución 1376/2007.[Accessed on: May 2013]. Availableat:http://www.msal.gov.ar/promin/archivos/pdf/resolucion-1376.pdf.

14. Sociedad Argentina de Pediatría. Comité Nacional de Crecimiento y Desarrollo. La Sociedad Argentina de Pediatría actualiza las curvas de crecimiento de niñas y niños menores de 5 años. Arch Argent Pediatr 2008;106(5):462-7.

15. Butte N, Garza C, Onis M. Evaluation of the Feasibility of International Growth Standards for School-Aged Children and Adolescents. J Nutr 2007;137(1):153-7.

16. Fernandez JR, Redden DT, Pietrobelli A, Allison DB. Waist circumference percentiles in nationally representative samples of African American, European-American, and Mexican-American children and adolescents. J Pediatr 2004;145(4):439-44.

17. U.S. Department of Health and Human Services, National Institute of Health. The fourth report on the Diagnosis, Evaluation and Treatment of High Blood Pressure in Children and Adolescents, September 1996. Revisado mayo2005. [Accessed on:July 3, 2013]. Available at: http:/ / www.nhlbi.nih.gov/health/prof/heart/hbp/hbp_ped. pdf.

18. Hamui-Sutton A, Varela-Ruiz M. La técnica de grupos focales. Inv Ed Med 2013;2(1):55-60.

19. Sociedad Argentina de Pediatría, Comité Nacional de Crecimiento y Desarrollo. Guías para la evaluación del crecimiento físico. 3ra ed. Buenos Aires: FUNDASAP, 2013.

20. Ministerio de Salud de la Nación. Formulario de empadronamiento, clasificación y seguimiento. En: Reglamento Operativo. Remediar+Redes, 2010:135-7. [Accessed on: June 2013]. Available at: http:/ /int ranet.r emedia r.gov. ar /intr anet/f iles/R_O_\%20 Remediar+Redes\%202010. pdf.

21. Mastrángelo S. Proyecto de fortalecimiento de la red de atención en el primer nivel. Neuquén: Ministerio de Salud, Subsecretaría de Salud; 2014.
22. Kovalskys I, Indart Rougiera P, Paz Amigoa M, De Gregorio MJ et al. Ingesta alimentaria y evaluación antropométrica en niños escolares de Buenos Aires. Arch Argent Pediatr 2013;111(1):9-15.

23. Linetzky B, Morello P, Virgolini M, Ferrante D. Resultados de la Primera Encuesta Nacional de Salud Escolar. Argentina, 2007. Arch Argen Pediatr 2011;109(2):111-6.

24. Cesani M, Luis M, Torres M, Castro L et al. Sobrepeso y obesidad en escolares de Brandsen en relación a las condiciones socioambientales de residencia. Arch Argen Pediatr 2010;108(4):294-302.

25. Zeberio N,Malpeli A,Apezteguia M,Carballo M, González $\mathrm{H}$. El estado nutricional de niños escolares y su relación con la tensión arterial. Arch Argent Pediatr 2013;111(2):92-7.

26. Caballero B. Prevención de la obesidad en edad temprana. Arch Argent Pediatr 2012:110(6):497-502.

27. Sapag M. Calidad de vida y discapacidad: la voz de las personas con discapacidad y sus familias como base para la acción institucional. Revista Nuestros Contenidos 2013;1(2): 65-77

28. Sapag L, Villa M, Berra M, Castillo J et al. Inequidad en los ingresos personales y familiares de Cutral Co y Plaza Huincul. Encuesta, curva de Lorenz e índice de Gini. Universidad Tecnológica Nacional. Unidad académica Confluencia. [Accessed on: June 2013]. Available at:http:// www.sapag.com.ar/images/opinion/informeLorenzCCoPH06.doc.

29. Abeyá Gilardon E, Calvo E, Durán P, Longo E, Mazza C. Vigilancia del crecimiento en los primeros años de vida. En: Evaluación del estado nutricional de niñas, niños y embarazadas mediante antropometría. Buenos Aires: Ministerio de Salud de la Nación. 2009:14.

30. Krichesky M. Escuela y Comunidad: desafíos para la inclusión educativa. Buenos Aires: Ministerios de Educación, Ciencia y Tecnología de la Nación, 2006.

31. Ardura Fernández J. Cardiología preventiva en pediatría. Obesidad, hipertensión y dislipidemia. [Accessed on: June 2013]. Available at: http:// www.secardioped.org/Descargas/PyB/LP_cap3.pdf.

32. Testa M. Pensar en salud. Buenos Aires: Lugar Editorial, 1993. 


\section{Annex 1}

\section{Cardiovascular risk factors form}

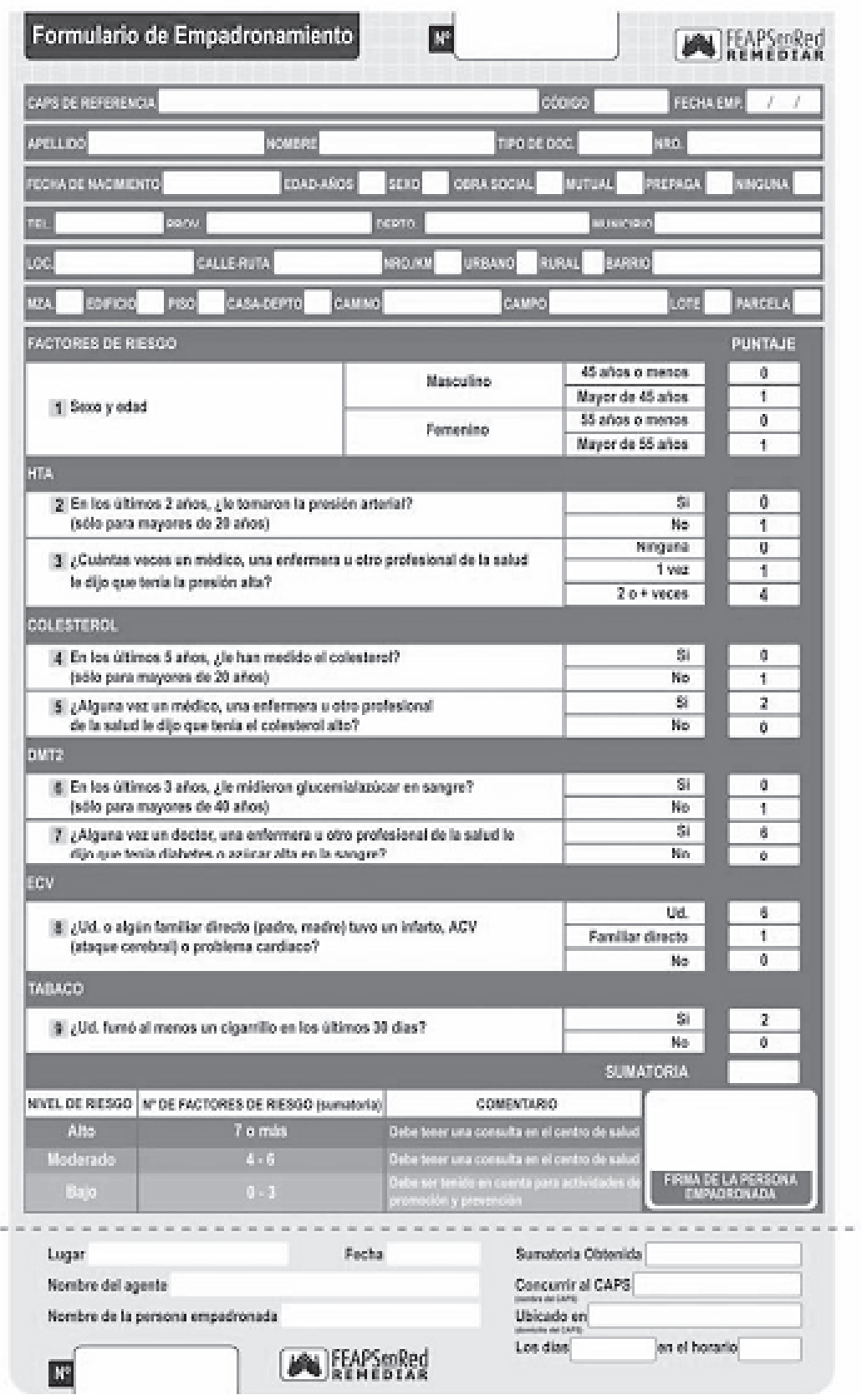

